\title{
A new sesquiterpene derivative from the fruit peel of Citrus limon (Linn.) Burm. $f$.
}

\author{
Shahnaz Sultana, M. Ali*, S. H. Ansari and Priyanka Bagri \\ Phytochemistry Research Laboratory \\ Department of Pharmacognosy and Phytochemistry \\ Faculty of Pharmacy, Jamia Hamdard (Hamdard University) \\ New Delhi-110062, India.
}

\begin{abstract}
A new sesquiterpene derivative of phloroglucinol glycoside isolated from the fruit peels of Citrus limon (Linn.) Burm.f. has been characterized as phloroglucinolyl-D-glucuronosyl-6"-longifolan-1"-ol-2"-one on the basis of spectral analyses.
\end{abstract}

\section{Key words}

Citrus limon, Rutaceae, fruit peels, sesquiterpene

\section{Introduction}

Citrus limon (Linn.) Burm.f. (Rutaceae) is an evergreen, aromatic shrub or small tree, grown in tropical and sub-tropical regions throughout the world and have been cultivated in southern China, Malaysia and sub Himalayan parts including Assam [1]. It is an important Indian herbal drug used as an antihypertensive, antihyperlipidemic, antidiabetic, anticancer, antioxidant and insecticidal remedy $[2,3,4]$. Phytochemical investigation of $C$. limon showed the presence of various flavonoids, coumarins, $\beta$ - and $\gamma$ - sitosterols, glycosides, and volatile oil $[5,6,7,8]$. 


\section{Results and Discussion}

Compound 1, named citrusyl longifolanone (Fig. 1), was obtained as pale yellow beads from chloroform-methanol (49:1) eluants. It formed green colour with ferric chloride indicating phenolic nature of the compound. Its IR spectrum displayed characteristics absorption bands for hydroxyl group (3505, $\left.3410 \mathrm{~cm}^{-1}\right)$, ester group $\left(1758 \mathrm{~cm}^{-1}\right)$, keto group $\left(1708 \mathrm{~cm}^{-1}\right)$ and aromatic ring $\left(1506,915,891,797 \mathrm{~cm}^{-1}\right)$. The mass spectrum generated an ion peak at $\mathrm{m} / \mathrm{z} 502$ formed after removal of water molecule from the molecular ion. Its molecular weight has been established by El mass spectrometry giving the molecular ion at $\mathrm{m} / \mathrm{z} 520\left[\mathrm{M}^{+}, \mathrm{C}_{27} \mathrm{H}_{36} \mathrm{O}_{10}\right]$. It was consistent with phenolic glycoside esterified with a tricyclic sesquiterpene. The ${ }^{1} \mathrm{H}$ NMR spectrum of 1 displayed four one-proton broad signal at $\delta 7.71,7.65,6.50$ and 5.48 assigned to aromatic $\mathrm{H}-1, \mathrm{H}-3, \mathrm{H}-5$ and anomeric $\mathrm{H}-1^{\prime}$, respectively. Two one-proton doublets at $\delta 4.94(\mathrm{~J}=12.3 \mathrm{~Hz})$ and $4.94(J=12.3 \mathrm{~Hz})$ were ascribed to $\mathrm{H}-5^{\prime}$ and $\alpha$-oriented $\mathrm{H}-1^{\prime \prime}$ methine protons. Two one-proton multiplets at $\delta 4.11$ and 3.12 and a one-proton broad signal at $\delta 3.36$ were associated with remaining hydroxymethine protons of the sugar moiety. Two three-proton broad signals at $\delta 1.19$ and 1.11 were accounted to C-14" and C-13" tertiary methyl protons. A six-proton broad signal at $\delta 1.02$ was ascribed to $\mathrm{C}-15^{\prime \prime}$ and $\mathrm{C}-12^{\prime \prime}$ methyl protons. The remaining methine and methylene protons resonated between $\delta 2.80-1.75$. The presence of the entire methyl signal in the range $\delta 1.19-1.02$ suggested their location on the saturated carbon. The ${ }^{13} \mathrm{C}$ NMR spectrum of 1 showed important signals for C-2" carbonyl carbon ( $\delta$ 208.03), C- $6^{\prime}$ ester carbon ( $\delta$ 170.24), aromatic carbons between $\delta$ 167.31-120.24, C-1' anomeric carbon at $\delta 110.20$, other carbons of the sugar moiety between $\delta$ 79.54-64.82, and methyl carbons $\delta 21.41$ (Me-12"), 19.67 (Me13"), 17.57 (Me-14") and 17.06 (Me-15"). The ${ }^{1} \mathrm{H}-{ }^{1} \mathrm{H}-\mathrm{COSY}$ spectrum of 1 showed correlation of $\mathrm{H}-1$ with $\mathrm{H}-3$ and $\mathrm{H}-5$; $\mathrm{H}-1^{\prime}$ with $\mathrm{H}-2^{\prime}$ and $\mathrm{H}-3^{\prime} ; \mathrm{H}-5^{\prime}$ with $\mathrm{H}-4^{\prime} ; \mathrm{H}-1^{\prime \prime}$ with $\mathrm{H}-6$ ", $\mathrm{H}-5^{\prime \prime}$ and $\mathrm{H}-3^{\prime \prime}$; $\mathrm{H}-13^{\prime \prime}$ with $\mathrm{H}-5^{\prime \prime}$ and $\mathrm{H}_{2}-11^{\prime \prime}$; and $\mathrm{H}_{3}-14^{\prime \prime}$ with $\mathrm{H}_{2}-8$ ", $\mathrm{H}_{2}-10^{\prime \prime}$ and $\mathrm{H}_{3}-15^{\prime \prime}$. The ${ }^{1} \mathrm{H}^{13}{ }^{13} \mathrm{C}$ spectrum of 1 exhibited correlation of $\mathrm{H}-1$ " with 
C-2", C-6" and C-6'; H-1' with C-2', C-6 and C-1; and $\mathrm{H}_{3}-12^{\prime \prime}$ with C-5" and C-6". Acid hydrolysis of 1 yielded phloroglucinol, D-glucuronic acid (TLC comparable) and a sesquiterpene of longifolane type. On the basis of these evidences the structure of 1 has been identified as phloroglucinolyl-D-glucuronosyl-6"-longifolan1 "-ol-2"-one.

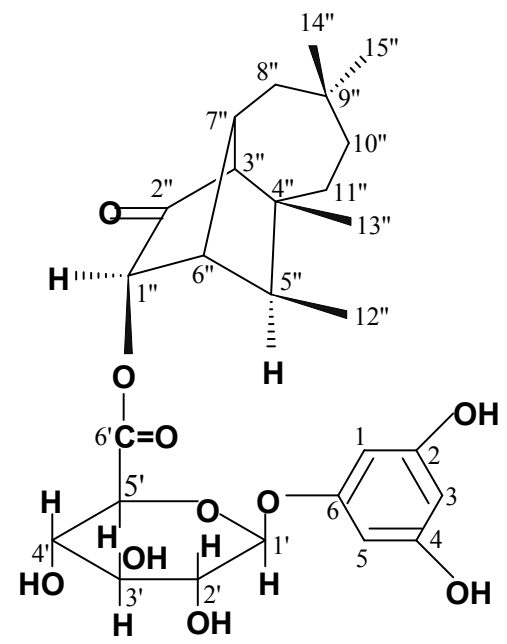

Fig. 1 Structure of 1

\section{Experimental}

\section{General procedure}

Melting points were determined on Perfit melting point apparatus and are uncorrected. FTIR: Jasco FT/IR-5000; UV: Lambda Bio 20 Spectrophotometer, $\mathrm{MeOH} ;{ }^{1} \mathrm{H}-\mathrm{NMR}$ (400 MHz): Advance DRY 400, Bruker Spectrospin, $\mathrm{CDCl}_{3} ;{ }^{13} \mathrm{C}$ NMR (75 MHz): Advance DRY 100, Bruker Spectrospin, $\mathrm{CDCl}_{3}$ with TMS as an internal standard; MS: FAB ionization on JEOL-JMS-DX 303; CC: Silica gel 
(Qualigens), 60-120 mesh; TLC: Silica gel G (Qualigens). Spots were visualized by exposure to iodine vapours, UV radiation and by spraying reagents.

\section{Plant material}

The fresh fruits of $C$. limon were procured from the Mehaurali market of Delhi and identified by Dr M.P. Sharma, Taxonomist, Department of Botany, Jamia Hamdard, New Delhi. A voucher specimen is deposited in the herbarium of the Phytochemical Research Laboratory, Faculty of Pharmacy, Jamia Hamdard, New-Delhi.

\section{Extraction}

The dried fruit peels $(1 \mathrm{~kg})$ were coarsely powdered and exhaustively extracted with methanol. The combined extracts were concentrated on a water-bath and dried under reduced pressure to get $200 \mathrm{~g}$ of dark brown mass. The viscous dark brown mass was dissolved in a little quantity of methanol and adsorbed on silica gel (60-120 mesh) for the preparation of slurry. It was dried and chromatographed over silica gel column packed in petroleum ether. The column was eluted with petroleum ether, chloroform and methanol successively in order of increasing polarity.

\section{Isolation and Characterization of 1}

Elution of the column with chloroform-methanol (49: 1) mixture furnished pale yellow beads of 1, recrystallized from acetone, $985.8 \mathrm{mg}(0.098 \%$ yield); $\mathrm{R}_{\mathrm{f}}: 0.52\left(\mathrm{CHCl}_{3}: \mathrm{MeOH}:: 6: 4\right) ;$ m.p. : $248-249{ }^{\circ} \mathrm{C}$; UV $\lambda_{\max }(\mathrm{MeOH}): 248$, $308 \mathrm{~nm}\left(\log \varepsilon\right.$ 5.3, 0.7); IR $v_{\max }(\mathrm{KBr}): 3505,3410,2920,2842,1758,1708,1506$, $1456,1366,1286,1263,1165,1035,915,891,797 \mathrm{~cm}^{-1} ;{ }^{1} \mathrm{H}$ NMR (DMSO - $\mathrm{d}_{6}$ ): $\delta 7.71(1 \mathrm{H}$, brs, H-1), $7.65(1 \mathrm{H}$, brs, H-5 ), $6.50(1 \mathrm{H}$, brs, H-3 ), 5.48 $\left(1 \mathrm{H}, \mathrm{brs}, \mathrm{H}-1^{\prime}\right), 4.94\left(1 \mathrm{H}, \mathrm{d}, J=12.3 \mathrm{~Hz}, \mathrm{H}-5^{\prime}\right), 4.50\left(1 \mathrm{H}, \mathrm{d}, J=12.1 \mathrm{~Hz}, \mathrm{H}-1^{\prime \prime}\right)$, $4.11\left(1 \mathrm{H}, \mathrm{m}, \mathrm{H}-4^{\prime}\right), 3.36\left(1 \mathrm{H}, \mathrm{brs}, \mathrm{H}-2^{\prime}\right), 3.12\left(1 \mathrm{H}, \mathrm{m}, \mathrm{H}-3^{\prime}\right), 2.80\left(1 \mathrm{H}, \mathrm{m}, \mathrm{H}-3^{\prime \prime}\right)$, $2.65\left(1 \mathrm{H}, \mathrm{m}, \mathrm{H}-8^{\prime \prime}\right), 2.59(1 \mathrm{H}, \mathrm{m}, \mathrm{H}-6 "), 2.49\left(1 \mathrm{H}, \mathrm{m}, \mathrm{H}-5^{\prime \prime}\right), 2.44(2 \mathrm{H}, \mathrm{m}$, $\left.\mathrm{H}_{2}-7^{\prime \prime}\right), 2.20$ (2H, m, $\left.\mathrm{H}_{2}-10^{\prime \prime}\right), 1.75$ (2H, m, $\left.\mathrm{H}_{2}-11^{\prime \prime}\right), 1.19$ (3H, brs, Me-14"), 1.11 
(3H, brs, Me-13"), 1.02 (6H, brs, Me-15", Me-12"); ${ }^{13} \mathrm{C}$ NMR (DMSO-d 6 ): б 141.71 (C-1), 143.35 (C-2), 120.24 (C-3), 143.35 ( C- 4), 141.71 (C-5), 167.31 ( C-6), $110.20\left(\mathrm{C}-1^{\prime}\right), 66.71\left(\mathrm{C}-2^{\prime}\right), 64.82\left(\mathrm{C}-3^{\prime}\right), 78.47\left(\mathrm{C}-4^{\prime}\right), 79.54\left(\mathrm{C}-5^{\prime}\right)$, 170.24 (C-6'), 77.45 (C-11"), 208.03 (C-2"), 58.01 (C-3"), 50.31 (C-4"), 37.66 (C-5") , 53.75 (C-6"), 36.20 (C-7") , 45.28 (C-8") , 46.51 (C-9") , 35.69 (C-10"), 29.22 (C-11"), 21.41 (C-12"), 19.67 (C-13"), 17.57 (C-14"), 17.06 (C-15"); MS $\mathrm{m} / \mathrm{z}: 520[\mathrm{M}]^{+}\left(\mathrm{C}_{27} \mathrm{H}_{36} \mathrm{O}_{10}\right)(5.3), 502\left[\mathrm{M}^{+}-\mathrm{H}_{2} \mathrm{O}\right]^{+}$(36.3).

\section{Hydrolysis of 1}

Compound 1 (35 mg) was heated with $1 \mathrm{~N} \mathrm{NaOH}$ solution $(5 \mathrm{ml})$ on a steam bath for $1 \mathrm{hr}$. The reaction mixture was extracted with $\mathrm{CHCl}_{3}(3 \times 5 \mathrm{ml})$. The organic layer was washed with $\mathrm{H}_{2} \mathrm{O}(2 \times 10 \mathrm{ml})$, dried $\left(\mathrm{Na}_{2} \mathrm{SO}_{4}\right)$ and evaporated to get longifolan-1-ol-2-one, IR $v_{\max }$ : 3350, $1710 \quad \mathrm{~cm}^{-1}$; EIMS m/z 236 $[\mathrm{M}]^{+}\left(\mathrm{C}_{15} \mathrm{H}_{24} \mathrm{O}_{2}\right)^{+}(1.1)$. The mother liquor on neutralization with diluted $\mathrm{HCl}$ yielded glucuronic acid and phloroglucinol (TLC comparable).

\section{References}

[1] Anonymous; The Wealth of India

A Dictionary of Indian Raw materials and Industrial products, Publication and Information Directorate, New Delhi, III, 1992: 623-679.

[2] Chaliha BP, Sastry GP, Rao PR. Flavonoids of the Assam Citrus peels.

Bull. Nat. Inst. Sci., India .1965; 31: 63-8.

[3] Chopin J, Roux B, Durix A. Flavone glycosides from lemon peel.

Compt. Rend. 1964; 259(18): $3111-3$.

[4] Codignola A, Shen A, Cova D, Perego R, Angelis LD, Clementi F Flavanoids extracted from Citrus limon as vasoactive drugs: pharmacodynamic and pharmacodynamic studies of Diosmin. Planta Medica 1992; 58(1): A 628.

[5] Gray Al and Watermann PG. Coumarins in Rutaceae. Phytochemistry 1978: 845-64. 
[6] Jung UJ, Lee MK, Park YB, Kang MA, Choi MS

Effect of citrus flavonoids on lipid metabolism and glucose-regulating enzyme mRNA levels in type-2 diabetic mice.

Int J Biochem Cell Biol. 2006:1-6.

[7] Miller EG, Porter JL, Binnie WH, Guo IY, Hasegawa S

Further studies on the anticancer activity of citrus limonoids.

J Agric Food Chem 2004; 52 (15): 4908-12.

[8] Ranganna S, Govindarajan VS, Ramana KVR.

Citrus fruits- varieties, chemistry, technology and quality evalution. Part II, chemistry, technology and quality evaluation.

CRC Crit. Rev. Food Sci. Nutr 1983; 18(4): 324, 338 and 352. 